\title{
The environmental balance of the Alta Val d'Agri: a contribution to the evaluation of the industrial risk and strategic sustainable development
}

\author{
S. Loperte and C. Cosmi \\ Institute of Methodologies for Environmental Analysis (IMAA) of the Italian National Research Council (CNR), \\ Tito Scalo (PZ), Italy
}

Correspondence to: S. Loperte (simona.loperte@imaa.cnr.it)

Received: 29 April 2014 - Published in Nat. Hazards Earth Syst. Sci. Discuss.: 5 January 2015

Accepted: 26 July 2015 - Published: 1 September 2015

\begin{abstract}
This study presents the preliminary environmental balance of the Alta Val d'Agri (Basilicata Region, Southern Italy), an area of great naturalistic interest characterized by the presence of huge oil and gas fields. The Driving Forces-Pressure-State-Impact-Responses (DPSIR) methodology was used to outline the background in terms of environmental impacts mainly caused by oil extraction activities, as well as potential existing responses. The study aims at providing stakeholders with an exhaustive framework to identify the existing data, the main sources of pollution, their potential impacts, the associated industrial risks and the existing policy strategies. Moreover, the DPSIR approach allows the identification of the vulnerable areas and the definition of targeted actions for a sustainable development of the area.
\end{abstract}

\section{Introduction}

The environmental balance is a voluntary tool that describes relationships both qualitatively and quantitatively between anthropogenic activities and the environment (Karageorgis et al., 2006) supporting either strategic planning or policy assessment (Nilsson et al., 2008). The DPSIR framework describes environmental problems through appropriate indicators and assesses the critical environmental issues that need to be addressed in local environmental plans (Naviglio et al., 2009). In particular, it allows the evaluation of environmental performances of industrial settlements and assesses their pressure on vulnerable areas, highlighting the most important impact factors and the associated potential industrial risks
(Piemonte Region and Regional Agency for the Protection of the Environment of Piemonte, 2013). The environmental balance provides a static representation of the analysed system in a given time period, evaluating its eco-efficiency and highlighting bottlenecks as well as the existing response strategies to environmental problems. In this process it is also possible to evaluate the variations of the state of the environment by comparing the environmental balances of different time periods, according to data availability and to identify the best available technologies to improve system's performances. This logical framework allows local authorities to move towards improving environmental quality through targeted actions and to evaluate the effectiveness of the policies in place. Anyway, as any conceptual scheme, a main drawback is the simplified representation of the environmental and social dynamics of a territory that are actually very complex. In particular, it would be useful to exploit the relationships among the indicators as well as to assign a priority to the different environmental issues in order to determine the most effective actions (Naviglio et al., 2009).

This paper presents a preliminary environmental balance of the Alta Val d'Agri industrial area providing stakeholders with an exhaustive framework in order to identify the anthropogenic impacts of the industrial settlement as a whole as well as to outline a possible path towards its sustainable development. This study shows an innovative application of the DPSIR, a well-established reference methodology to collect and process environmental data, in which different aspects not fully addressed in previous studies were integrated. A preliminary application of this methodology to an industrial area is reported in Cosmi et al. (2006). 
The Alta Val d'Agri is a peculiar area in which there are the hugest oil field in Italy and a naturalistic area (the Appennino Lucano, Val d'Agri, Lagonegrese National Park). The presence of an oil/gas treatment centre, Val d'Agri Oil Centre (COVA), where the extracted fluid is collected, separated into crude oil, gas and water and further processed, undoubtedly represents a significant source of environmental impact and important associated industrial risks. Therefore, an in-depth characterization of all anthropogenic impacts as a whole is fundamental in outlining the framework on which interventions and recovery plans should be developed.

\section{The methodological approach}

This study used an ad hoc survey methodology to obtain a detailed characterization of the industrial area as well as to outline and monitor the relationships between the anthropogenic activities and the environment.

This methodology, based on the DPSIR model implemented by the European Environment Agency (EEA, 1995) combines a qualitative and quantitative assessment to evaluate the integrated effect of the dominant factors causing the main environmental impacts and to assess their effects. This preliminary analysis was essential to identify the strengths and weaknesses of the study area, the potential risks as well as to define strategies and measures to promote its sustainable development.

A detailed survey of existing activities focusing on industrial activities was carried out utilizing selected indicators. The indicators checklist was complemented by customized questionnaires submitted to all the industries located in the study area $(74.5 \%$ of respondents corresponding to $88.4 \%$ of employers and about $60 \%$ of total energy consumption), aimed at providing additional qualitative information for a thorough description of the industrial activities including existing energy-environmental management systems.

The following provides a summary description of the DPSIR methodology and the selected indicators are reported.

The DPSIR methodology represents an upgrade of the former PSR (Pressure-State-Response) model adopted by the Organisation for Economic Cooperation and Development (OECD, 1994). Its basic concept deals with the causality relationship among the pressures put forth by human activities on the environment and its changes in terms of natural resources depletion and degradation.

Specific indicators in this framework are used to monitor each stage of the DPSIR process, constituting a sound database for policy making and assessment. These indicators are essential in quantifying anthropogenic pressures and impacts and, consequently, in assessing the state of environment in order to support policy evaluation studies and to provide key information to end-users. In particular, the environmental indicators illustrate all the elements of the causal chain between anthropogenic activities and their environ- mental effects as well as community responses (Niemeijer et al., 2012).

Therefore, appropriate socio-economic and environmental indicators were selected from the European Environment Agency (EEA, 2012) and the Institute for the Protection and Environmental Research (ISPRA, 2012) catalogues to characterise the Alta Val d'Agri industrial area. These indicators, following the European Environmental Agency guidelines (EEA, 2005), reported the information related to Environment (air, soil, water), Resources (energy, raw and secondary materials, waste), Socio-Economic (policy, business, society, end-use sectors) as well as to highlight the main criticalities in terms of industrial risks.

The list of indicators together with the DPSIR drivers and the reference components (input-output matrices) are reported in Table 1.

All the collected information was filled in Excel tables including: company fact sheet, raw materials processed, manufactured and used, water use, energy use, environmental authorizations and compliance with International Organization Standardisation (ISO) standards.

The collected data was also utilised to populate a thematic database on the industrial areas of the Basilicata implemented by the Department of Productive Activities of the Basilicata Region.

\section{The Alta Val d'Agri industrial district}

The Alta Val d'Agri industrial district is located in the Basilicata region (Southern Italy) in the towns of Viggiano and Grumento Nova (Fig. 1a and b). The most important activities in the study area include a water treatment plant, a 4.5 MW PV plant, a 5.2 MW CHP plant, a 7 MW CC plant and COVA.

The industrial area is very close to the Appennino Lucano, Val d'Agri, Lagonegrese National Park and to many builtup areas. It is also located in the Agri River Basin, in the neighbourhoods of the Casale stream, a tributary of the Agri River.

As a first step a survey of the infrastructures and services was carried out (Table 2).

Moreover, the industrial area has still not got a toponymy and there are no schools, hospitals, sport or leisure centres in the surrounding areas.

The industry activities related to COVA, owned by Ente Nazionale Idrocarburi (ENI), represent the most significant sources of environmental impact. In fact, besides being the major integrated energy company in Italy, ENI is also the biggest operator in the Val d'Agri $(60.77 \%$ of exploitation concessions). ENI started its activity in Basilicata in 1996, with the Monte Alpi production line, whereas COVA started its production in 2001. Currently there are five production lines from 26 wells, with a maximum capacity 
Table 1. Main indicators for the DPSIR of Alta Val d'Agri industrial area.

\begin{tabular}{|c|c|c|}
\hline DPSIR drivers & Indicators & Component (input-output matrices) \\
\hline \multirow[t]{3}{*}{ Driving forces $(\mathrm{D})$} & $\begin{array}{l}\text { Population, } \\
\text { number of enterprises, } \\
\text { number of employees by sector } \\
\text { GDP }\end{array}$ & Socio-economic/, society, business \\
\hline & $\begin{array}{l}\text { Barrel of oil extracted } \\
\mathrm{Sm}^{3} \text { day }^{-1} \text { of natural gas }\end{array}$ & $\begin{array}{l}\text { Environment } \\
\text { Socio-economic/industry }\end{array}$ \\
\hline & Number and typology of freight transport (fuels, raw materials, goods) & Socio-economic/transport \\
\hline \multirow[t]{7}{*}{ Pressures $(\mathrm{P})$} & Land use & Environment/soil \\
\hline & Natural resources use & Resources/raw material \\
\hline & Water extraction, consumption and waste & Environment/water \\
\hline & Energy production and consumption & Resources/energy \\
\hline & $\begin{array}{l}\text { Atmospheric emissions by sector }\left(\mathrm{CO}_{2}, \mathrm{SO}_{2}, \mathrm{NO}_{x}, \mathrm{VOC}, \mathrm{CO}, \mathrm{TSP} \text {, }\right. \\
\left.\mathrm{PM}_{10}, \mathrm{PM}_{2.5}, \mathrm{NO}_{2}, \mathrm{O}_{3}, \mathrm{SO}_{2}\right)\end{array}$ & Environment/air \\
\hline & $\begin{array}{l}\text { Waste produced by industry sector (special hazardous waste, special } \\
\text { non-hazardous waste) }\end{array}$ & Resources/waste \\
\hline & Integrated Environmental Authorization - AIA & Socio-economic/industry \\
\hline \multirow[t]{2}{*}{ State (S) } & $\begin{array}{l}\text { Atmospheric pollutant concentrations }\left(\mathrm{SO}_{2}, \mathrm{NO}_{x}, \mathrm{VOC}, \mathrm{CO}, \mathrm{TSP} \text {, }\right. \\
\left.\mathrm{PM}_{10}, \mathrm{NO}_{2}, \mathrm{O}_{3}\right)\end{array}$ & Environment/air \\
\hline & $\begin{array}{l}\text { Chemical-Microbiological parameters }\left(\mathrm{BOD}_{5}, \mathrm{COD}, \mathrm{PH} \text {, organic sub- }\right. \\
\text { stances, fecal contamination indices) } \\
\text { Ecological parameters (SECA, LIM, IBE) }\end{array}$ & Environment/water \\
\hline Impacts (I) & $\begin{array}{l}\text { All indicators reported in the above categories to assess the variations } \\
\text { and changes on the environment } \\
\text { other indicators to assess the damages on eco-system, human health, } \\
\text { economic }\end{array}$ & $\begin{array}{l}\text { Environment/air, water, soil } \\
\text { socio-economic/society, business }\end{array}$ \\
\hline Responses (R) & $\begin{array}{l}\text { Environmental evaluation and certification } \\
\text { number of RES plants installations } \\
\text { policies and strategies at national, regional, provincial and municipal } \\
\text { level (e.g. SEAP, mitigation and adaptation plans, other thematic plans) } \\
\text { financial measures and incentives to promote RES and EE deployment } \\
\text { other actions promoted by Local Authorities and Associations cate- } \\
\text { gories for environmental protection and sustainable development }\end{array}$ & $\begin{array}{l}\text { Environment/air, water, soil } \\
\text { Socio-economic/policy, business, } \\
\text { society }\end{array}$ \\
\hline
\end{tabular}

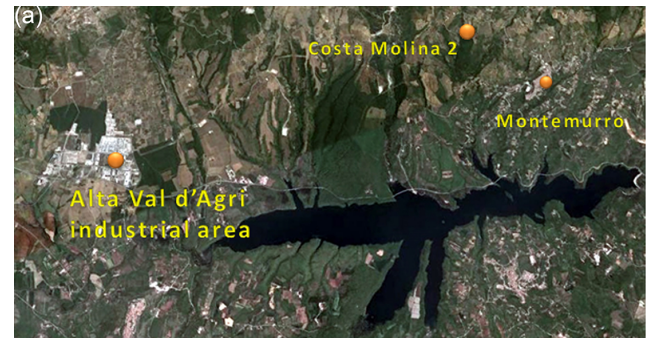

(b)

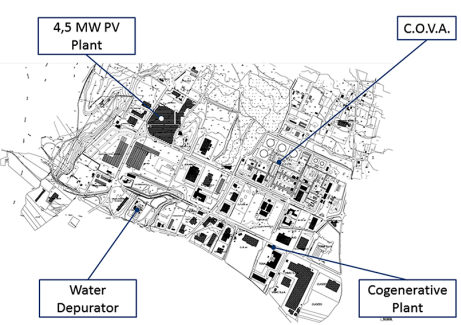

Figure 1. (a) Map of the analyzed area in which are highlighted the Alta Val d'Agri industrial area, the location of wastewater reinjection well (Costa Molina 2) and Montemurro (source: Google Earth, 2013), and (b) site plan of Alta Val d'Agri industrial district with the most relevant industrial activities highlighted by the boxes (Source: CNR-IMAA elaboration on Bonaduce's image). 
Table 2. State of infrastructures of Alta Val d'Agri industrial area.

\begin{tabular}{|c|c|c|}
\hline Infrastructures & Availability & Situation \\
\hline Electricity grid & $X$ & Completed \\
\hline Natural gas grids & $\mathrm{X}$ & $\begin{array}{l}\text { SNAM grid in the area identified as "ex-219" } \\
\text { An ASI grid connecting all the industries un- } \\
\text { der construction }\end{array}$ \\
\hline Oil pipeline & $\mathrm{X}$ & $\begin{array}{l}\text { A } 136 \mathrm{~km} \text { pipeline connects the COVA in } \\
\text { Viggiano with the ENI's refinery located in } \\
\text { Taranto }\end{array}$ \\
\hline $\begin{array}{l}\text { High voltage grid } \\
(\geq 15 \mathrm{~kW})\end{array}$ & $X$ & About $1.5 \mathrm{~km}$ North \\
\hline Drinking and industrial water & $X$ & Completed \\
\hline Public lighting & $\mathrm{X}$ & Completed \\
\hline Sewerage & $X$ & $\begin{array}{l}\text { A water drainage system and a sewage treat- } \\
\text { ment plant }\end{array}$ \\
\hline $\begin{array}{l}\text { Roads } \\
\text { Highways and freeways } \\
\text { Other roads }\end{array}$ & $X$ & $\begin{array}{l}\text { The state road S.S. } 598 \text { Fondo Valle d'Agri } \\
\text { from Athena Scalo to Policoro connects the } \\
\text { A } 3 \text { highway to the SS } 106 \text { Jonica. } \\
\text { Internal roads are not properly maintained, } \\
\text { with no road markings and insufficient traffic } \\
\text { signs }\end{array}$ \\
\hline Railway & & $\begin{array}{l}\text { The nearest town with a railway station is } \\
\text { Potenza, the chief town }\end{array}$ \\
\hline Telephone line & $\mathrm{X}$ & Completed \\
\hline $\begin{array}{l}\text { Internet line (ADSL, optical fiber, } \\
\text { etc) }\end{array}$ & $\mathrm{X}$ (partially available) & $\begin{array}{l}\text { An optic fiber ring is under construction to } \\
\text { serve the ENI offices }\end{array}$ \\
\hline
\end{tabular}

of about $16500 \mathrm{~m}^{3}$ day $^{-1}$ (about 104000 barrels day $^{-1}$ ) and 3.1 million $\mathrm{Sm}^{3}$ day $^{-1}$ of natural gas.

The extracted fluid is processed through a three-phase system that separates the oil extracted into crude oil, gas and water. Crude oil is transported through an underground pipeline of about $136 \mathrm{~km}$ length to the ENI refinery in Taranto, located in neighbouring Apulia region. Natural gas, pre-treated at COVA, is delivered to the Società Nazionale Metanodotti (SNAM) national grid (ENI, 2013) and the process wastewater is re-injected into the subsoil through the Costa Molina Sud injection well.

The oil industry causes a high impact on all environmental matrices (air, water, soil), on vegetation and wildlife, and ultimately on human health, during all of the processing phases, from drilling to transportation. (Sviluppo Basilicata, 2011)

In fact, COVA is classified as a major hazardous plant (one of 10 hazardous plants located in Basilicata) and should comply with The Seveso 3EU Directive (EU/2012/18; 2012) for the regulation of major accident hazard sites in order to limit their consequences for human health and the environment. In compliance with the Seveso 3EU Directive, COVA defined an emergency plan and according to Intergovernmental Panel on Climate Change (IPCC) directives (Directive 2008/1/EC), requested an Integrated Environmental Authorization (IEA, 2011).
It should also be noticed that the oil fields are located in a high seismic risk area characterized by a series of important active trans-current tectonic faults that make the territory particularly unstable. In fact, according to Basilicata Law no. 9/2011, 2011, the Val d'Agri belongs to the 1b vulnerability class characterized by a Peak Ground Acceleration (PGA) of $0.275 \mathrm{~g}$ and a maximum magnitude of 5.8 and these geographic conditions contribute heavily to increasing the vulnerability of the territory.

\subsection{Preliminary Results and discussion}

\subsubsection{Driving forces}

A systematic collection of data on energy, environmental and socio-economic aspects was performed to identify those activities that cause major impacts. Starting from the data provided by the Consortium for Industrial Development (ASI) of Potenza and taking into account the European industrial activity classification (Eurostat, 2008), a detailed socioeconomic characterization of business activities was carried out. The summary results are reported in Table 3 .

The characterisation of the industry sector pointed out the coexistence of medium and large enterprises with a high level of technological innovation in the petrochemical sector and a prevalence of micro-manufacturing firms (Sviluppo Basilicata, 2011). 
Among the small and medium enterprises, the most relevant sectors in terms of employees are manufacturing (small businesses), construction and related industries (stone processing, production of lime and concrete, metal and wood carpentry), as well as professional, scientific and technical activities.

The transport of materials and finished goods inside and outside the industrial area represents one of the critical aspects with a significant impact on environment. In fact, due to the absence of a railway, road transport is carried by truck along the SS 598 Fondo Valle dell'Agri which connects the industrial area to the motorway. Therefore, the truck traffic associated with the transport of goods represents a main source of environmental pollution because urban traffic is negligible.

\subsubsection{Pressures}

The use of material resources plays a crucial role in the generation of environmental pressures directly caused by primary activities and indirectly through their feedback to the natural environment in terms of air pollutants, water discharges, waste production and land use (Eurostat, 2011).

Resource productivity is the main indicator selected by the European Commission to monitor sustainable consumption and production (Council of the European Union, 2006).

The Alta Val d'Agri industrial district covers an area of about 190 ha of which about 168 ha is built-up, 34 ha is public green and about 6 ha is not suitable for building (ASI, 2012).

The use of raw materials (typology and quantities) was estimated taking into account the Legislative Decree no. 152/99 tables (Legislative Decree no. 152/99). The data provided by the ASI, referred to a sample of 13 companies, was integrated and extrapolated to 2013 utilising the results of a survey conducted in the early months of 2013 (Table 4).

Very detailed data concerning water use was provided by the Aziende Riunite Gestione Aree Industriali Potentine (ARGAIP, 2012), a consortium of companies responsible for the operating and maintenance of industrial plants. Water consumption for industrial and civil uses by sector is shown in Figs. 2 and 3. The drinking water is provided by the local aqueduct whereas industrial water is supplied from the wastewater treatment plant. These infrastructures are managed by the ASI.

As shown in Fig. 2, mining and quarrying (both for civil and industrial use) and manufacturing (civil use) have the highest consumption (about $82.6 \%$ for civil use and $94.6 \%$ for industrial use in mining and quarrying, respectively, and about $15.0 \%$ for civil use and $4.3 \%$ for industrial use in manufacturing). As shown in Fig. 3, professional activities $(0.77 \%)$ and water supply $(0.70 \%)$ are the most significant water consumers in the civil sector, whereas construction $(0,47 \%)$ and wholesale and retail trade $(0.28 \%)$ are the most relevant consumers in the industrial one.

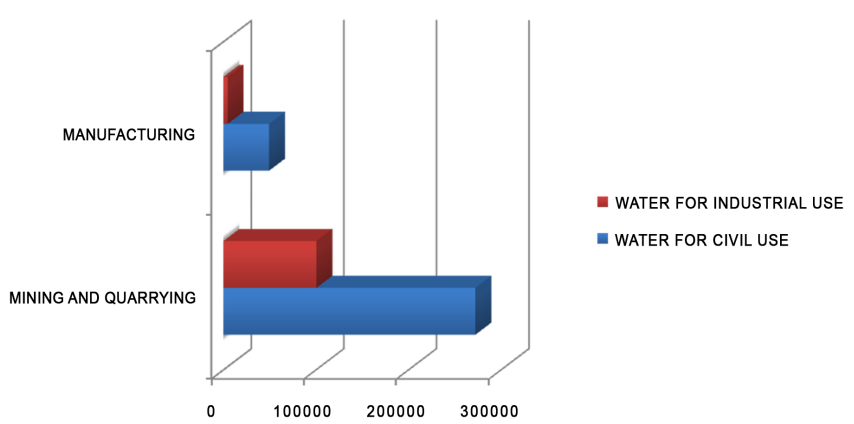

Figure 2. Water consumption for industrial and civil use for mining and quarrying and manufacturing sectors $\left[10^{6} \mathrm{~m}^{3}\right]$ (Source: ARGAIP Potenza).

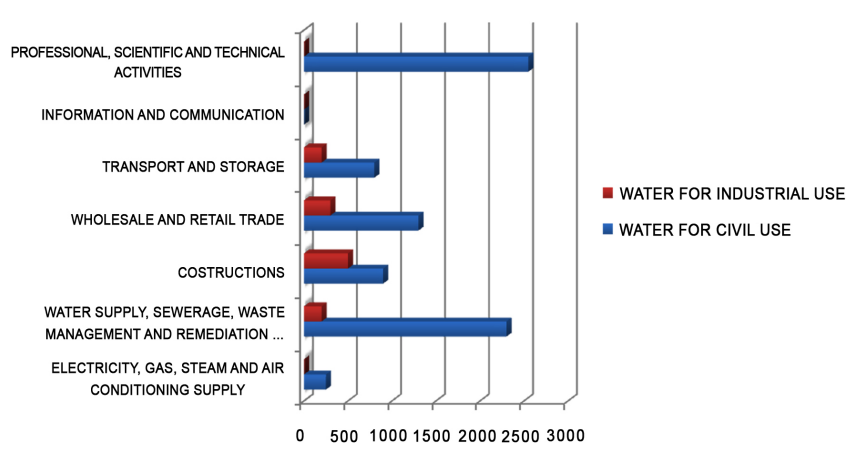

Figure 3. Water consumption for industrial and civil use by industrial sector $\left[\mathrm{m}^{3}\right]$ (Source: ARGAIP Potenza).

Waste flows were also investigated by a survey of the Model for Environmental Declaration-MUD, i.e. the annual declaration on the total amounts and characteristics of waste produced released by industries in compliance with the Italian legislation (Legislative Decree no. 152/06, and its subsequent modification and Ministerial Decree no. 52/2011, 2011).

Taking into account the information provided by the MUDs declarations of the Alta Val d'Agri industries for the years 2010-2011 (Chamber of Commerce and Industry of Potenza, 2013) and other additional data provided by the Regional Agency for the Environment of the Basilicata Region (ARPAB, 2012), waste flows (Hazardous Waste-HW and Non-Hazardous Waste-NHW) were estimated.

In particular, the amounts of hazardous waste and nonhazardous waste by sector estimated by the ARPAB are reported in Fig. 4.

An estimation of hazardous waste amount is reported in Fig. 5 (CNR-IMAA elaborations on ARPAB data) showing a significant contribution of oil extraction activities (i.e. mining and quarrying sector) especially oily wastewater (e.g. water used to wash equipment and tanks, drain water, oil sludge, etc.).

An estimation of non-hazardous waste amount is reported in Fig. 6 (CNR-IMAA elaborations on ARPAB data). Manu- 
Table 3. Distribution of enterprises and employees by industrial sector for Alta Val d'Agri industrial area (the most significant sectors in bold).

\begin{tabular}{lll}
\hline Indicators & \multicolumn{1}{l}{ Reference period: 2012-2013 } \\
\hline Total number of employees & \multicolumn{1}{l}{ Distribution of enterprises and employees by sector } & \\
\hline & No. of enterprises & No. of employers \\
\hline Sectors of activity & $\mathbf{7}$ & $\mathbf{2 1 8}$ \\
\hline Mining and quarrying & $\mathbf{1 8}$ & $\mathbf{4 4 0}$ \\
Manufacturing & 3 & 6 \\
Electricity, gas, steam and air conditioning supply & 5 & 54 \\
Water supply, sewerage, waste management and remediation activities & $\mathbf{2 1 0}$ \\
Construction & $\mathbf{5}$ & 28 \\
Wholesale and retail trade & 6 & 44 \\
Transport and storage & 3 & 2 \\
Information and communication & 1 & 1 \\
Real estate activities & 1 & $\mathbf{1 1 6}$ \\
Professional, scientific and technical activities & $\mathbf{1 0}$ & 1 \\
Administrative and support service activities & 1 & 3 \\
Education & 1 & 3 \\
Other service activities & 1 & \\
\hline
\end{tabular}

Table 4. Flows of raw materials and finished product per sector of activity.

\begin{tabular}{lll}
\hline Indicator & & \\
\hline Raw materials input/output & $\begin{array}{l}\text { Raw } \\
\text { materials } \\
\text { (tons) }\end{array}$ & $\begin{array}{l}\text { Finished } \\
\text { product } \\
\text { (tons) }\end{array}$ \\
\hline Sectors of activities & 34763 (ktoe) & \\
\hline B Mining and quarrying & 83016.6 & 55094 \\
\hline C manufacturing & - & - \\
\hline F constructions & - & 2000 \\
\hline $\begin{array}{l}\text { G wholesale and retail trade; } \\
\text { repair of motor vehicles and } \\
\text { motorcycles }\end{array}$ & & \\
\hline
\end{tabular}

facturing activities and, more specifically, machineries and equipment manufacturer (NEC) contribute significantly to the production of non-hazardous waste, whereas mechanical activities produce a large amount of hazardous waste (emulsions and solutions for machinery, without halogen and packaging containing residues of dangerous or contaminated substances).

According to the MUD declarations and the European Waste Catalogue (EWC) classification a further disaggregation of industrial waste flows was estimated (Table 5).

The evaluation of the waste flows did not take into account the sludge from urban waste water treatment as well as $\mathrm{Mu}-$ nicipal Solid Wastes (MSW) because it was not possible to

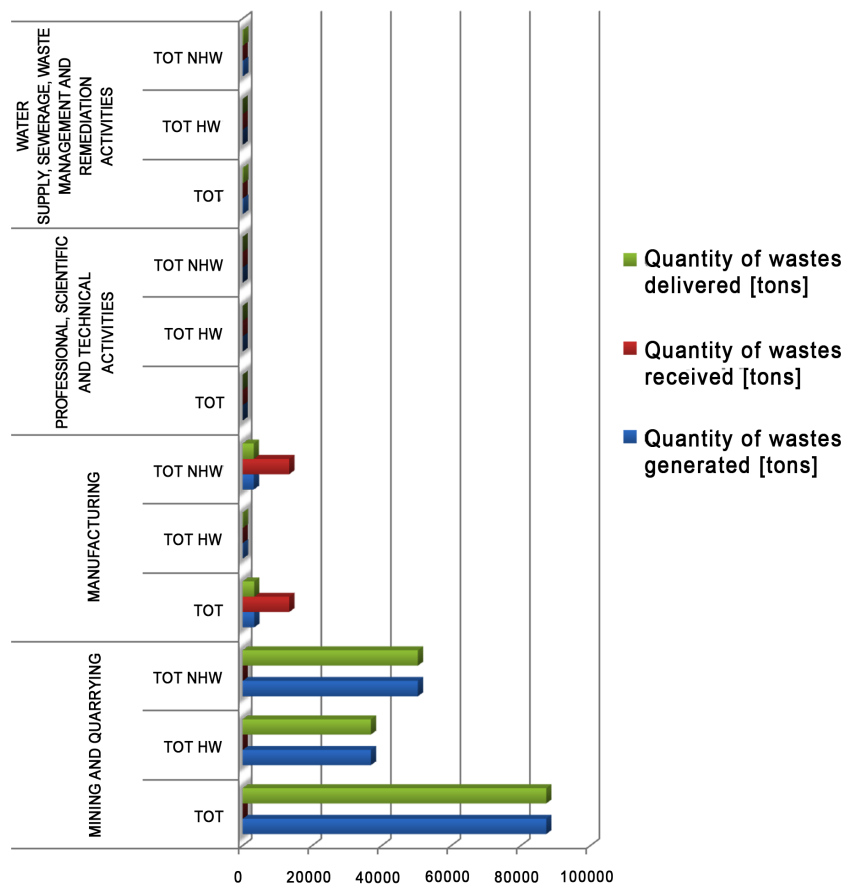

Figure 4. Hazardous (HW) and non-hazardous (NHW) waste flows by sector. Source: ARPAB.

distinguish the amounts produced by the industrial district by the whole amount of MSW produced by Viggiano and Grumento Nova municipalities.

Energy consumption is an important indicator to assess the impact of the end-use sectors, with particular attention to energy-intensive activities (e.g. power generation, refineries, 


\section{HAZARDOUS WASTES}

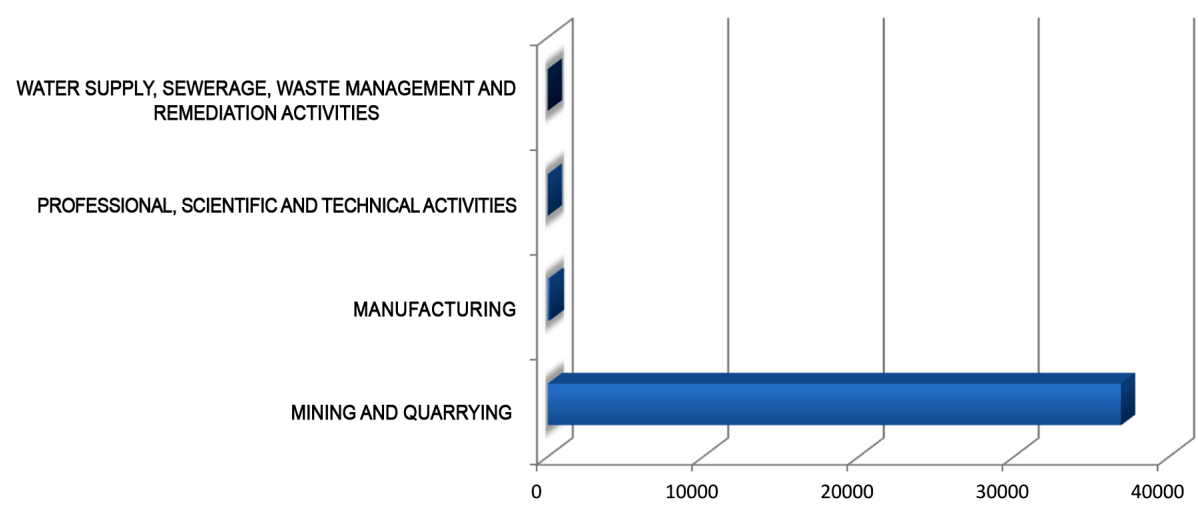

Figure 5. Hazardous waste (HW) flows by sector [tons] (CNR- IMAA elaborations).

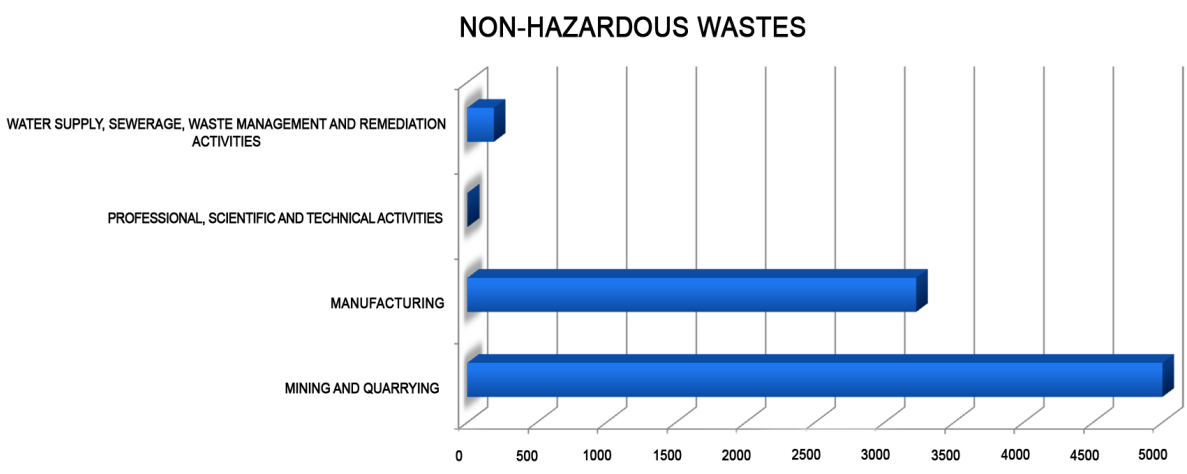

Figure 6. Non-hazardous waste (NHW) flows by sector [tons] (source: CNR-IMAA elaboration on data from ARPA Basilicata).

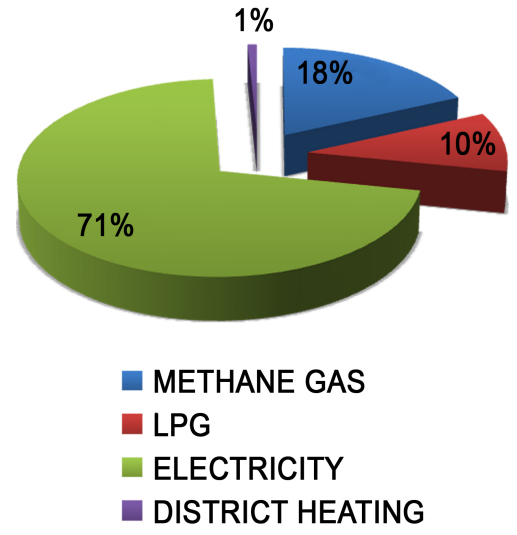

Figure 7. Energy consumption by energy carrier - Industry (2012).

steel and aluminium industries, etc.) characterized by high specific electrical and thermal energy consumption. The Alta Val d'Agri industrial district has two power plants: (a) the CHP Azimut, a 5.2 MW natural gas co-generative plant connected to district heating network of about $2 \mathrm{~km}$, and (b) the CC power plant Nuova Azimut, a $7 \mathrm{MW}$ natural gas fuelled plant. The Azimut plant was closed in 2013 and will be dis- mantled in the near future therefore it cannot be used to supply the district heating thermal energy demand.

The total consumption of the industry sector (about 7300 toe) was estimated from the average unitary energy consumption for the whole Basilicata industry sector (e.g. the total energy consumption by sector by working unit) (ENEA, 2012), considering as a proxy variable the number of employees by sector of the Alta Val d'Agri industries in 2012 and the percentage of use of energy carriers estimated by a direct survey (Fig. 7).

Figure 7 highlights that electricity is the most used fuel (71\%) followed by natural gas ( $18 \%)$, LPG $(10 \%)$ and thermal energy from the district heating $(1 \%)$. This fuel mix represents a major environmental bottleneck due to the unfinished natural gas network that cannot fulfil the whole industrial energy demand.

In this evaluation, COVA consumption as well as the consumption of the two other power plants are not included. In particular, COVA consumption was provided by the ENI company (Table 6).

Energy consumption constitutes the basis to estimate the pollutant emissions due to combustion processes and to identify the most dangerous activities. The atmospheric emis- 
Table 5. Waste flows according to EWC classification (source: ARPAB internal communication).

\begin{tabular}{|c|c|c|c|c|}
\hline EWC & $\begin{array}{l}\text { Description of wastes } \\
\text { of wastes }\end{array}$ & $\begin{array}{l}\text { Quantity of waste } \\
\text { generated [tons] }\end{array}$ & $\begin{array}{l}\text { Quantity of waste } \\
\text { received [tons] }\end{array}$ & $\begin{array}{l}\text { Quantity of waste } \\
\text { delivered [tons] }\end{array}$ \\
\hline 01 & $\begin{array}{l}\text { Wastes resulting from exploration, min- } \\
\text { ing, quarry, as well as by physical or } \\
\text { chemical treatment of minerals }\end{array}$ & 26371.28 & 4.58 & 26359.30 \\
\hline 03 & $\begin{array}{l}\text { Wastes from wood processing and the } \\
\text { production of panels and furniture, pulp, } \\
\text { paper and paperboard }\end{array}$ & 45.70 & 0.00 & 46.60 \\
\hline 05 & $\begin{array}{l}\text { Wastes from petroleum refining, natural } \\
\text { gas purification and pyrolytic treatment of } \\
\text { coal }\end{array}$ & 190.68 & 0.00 & 190.68 \\
\hline 06 & $\begin{array}{l}\text { Wastes from inorganic chemical pro- } \\
\text { cesses }\end{array}$ & 0.38 & 0.00 & 0.38 \\
\hline 07 & Wastes from organic chemical processes & 700.41 & 0.00 & 700.41 \\
\hline 08 & $\begin{array}{l}\text { Wastes from the manufacture, formula- } \\
\text { tion, supply and use of coatings (paints, } \\
\text { varnishes and vitreous enamels), adhe- } \\
\text { sives, sealants and printing inks }\end{array}$ & 0.39 & 0.00 & 0.40 \\
\hline 10 & Wastes from thermal processes & 41.26 & 0.00 & 41.26 \\
\hline 12 & $\begin{array}{l}\text { Wastes from shaping and physical and } \\
\text { mechanical surface treatment of metals } \\
\text { and plastics }\end{array}$ & 636.65 & 0.00 & 633.78 \\
\hline 13 & $\begin{array}{l}\text { Oil wastes and wastes of liquid fuels (ex- } \\
\text { cept edible oils, and those in chapters } 05 \text {, } \\
12 \text { and 19) }\end{array}$ & 9.69 & 0.00 & 10.38 \\
\hline 14 & $\begin{array}{l}\text { Organic solvents, refrigerants and propel- } \\
\text { lants (except } 7 \text { and } 8 \text { ) }\end{array}$ & 0.02 & 0.00 & 0.02 \\
\hline 15 & $\begin{array}{l}\text { Waste packaging, absorbents, wiping } \\
\text { cloths, filter materials and protective } \\
\text { clothing (not otherwise specified) }\end{array}$ & 1533.99 & 0.00 & 1530.82 \\
\hline 16 & Wastes not otherwise specified in the list & 59622.78 & 0.00 & 59619.63 \\
\hline 17 & $\begin{array}{l}\text { Wastes from construction and demoli- } \\
\text { tion wastes (including excavated soil from } \\
\text { contaminated sites) }\end{array}$ & 210.32 & 13403.63 & 212.06 \\
\hline 19 & $\begin{array}{l}\text { Wastes from waste treatment plants, } \\
\text { wastewater treatment plants off-site, as } \\
\text { well as clean water and its preparation for } \\
\text { industrial use }\end{array}$ & 154.64 & 0.00 & 154.64 \\
\hline 20 & $\begin{array}{l}\text { Municipal wastes (household waste and } \\
\text { similar products to commercial and indus- } \\
\text { trial activities and the institutions) wastes } \\
\text { including waste collection }\end{array}$ & 1340.11 & 0.00 & 1340.01 \\
\hline
\end{tabular}

sions were estimated according to the CORINAIR methodology (EMEP/EEA, 2009), considering the emission factors of the SINA Net (SINA Net, 2012) and the Agenzia Nazionale Protezione Ambiente Centro Tematico Nazionale-Atmosfera
Clima Emissioni guidebook (ANPA CTN-ACE, 2002) and utilising suited sectoral proxy variables (e.g. socio-economic and demographic indicators). Figures 8 and 9 show the pollutant emissions from energy processes from the main end-use 
Table 6. Energy consumption of COVA (source: ENI, 2013).

\begin{tabular}{llll}
\hline Energy flows & 2009 & 2010 & 2011 \\
\hline Gross energy consumption [internal production plus purchased energy] [MWh] & 148843 & 155212 & 158151 \\
\hline Net energy consumption [produced plus purchased/sold energy] [MWh] & 131933 & 144281 & 153949 \\
- of which produced electricity [MWh] & 148329 & 153196 & 144467 \\
- of which energy purchased by other companies [MWh] & 514 & 2016 & 13683 \\
- of which energy sold to other companies [MWh] & 16910 & 10931 & 4202 \\
\hline Net electricity consumption [MWh] per thousand of produced barrels & 4621 & 4497 & 4429 \\
\hline
\end{tabular}

Table 7. Total yearly emissions from COVA (Source: ENI, 2013).

\begin{tabular}{llll}
\hline Reference year & 2009 & 2010 & 2011 \\
\hline & \multicolumn{3}{c}{ thousands of tons } \\
\hline GHGs direct emissions & 497.66 & 469.78 & 394.5 \\
- of which $\mathrm{CO}_{2}$ from combustion and process & 307.57 & 273.8 & 205.1 \\
- of which $\mathrm{CO}_{2}$ equivalent from flaring & 72.82 & 67.28 & 49.77 \\
- of which $\mathrm{CO}_{2}$ equivalent from $\mathrm{CH}_{4}$ & 117.26 & 128.71 & 139.64 \\
\hline $\mathrm{SO}_{2}$ emissions & 0.032 & 0.028 & 0.039 \\
$\mathrm{NO}_{x}$ emissions & 0.536 & 0.5 & 0.333 \\
\hline
\end{tabular}

sectors, emphasising the high contribution from manufacturing.

COVA emissions for the period 2009-2011 provided by ENI are reported in Table 7.

The emissions from non-energy process were estimated by using the solvent use as an activity indicator. Their amount constitutes an additional $24.5 \%$ of the total yearly emissions on average (data not shown).

Besides the evaluation of yearly pollutant emissions the analysis also concerned the localization of pollution sources with a main reference to point sources.

A census of the emissions permits (Legislative Decree no. 152/2006) and the Integrated Environmental Authorization granted by the Basilicata Region survey was therefore carried out to integrate the information obtained directly by the industries. This investigation was also aimed at improving the physical-chemical characterization of the pollution sources for further studies.

\subsubsection{State}

The state of the environment and the impacts of the anthropogenic activities in the study area were assessed by investigating air and water quality and by considering the companies owning recognised environmental certifications.

Most of the data were provided by the Environmental Observatory of the Val d'Agri (OAVDA, 2013) and from monitoring campaigns. In particular, the official data were provided by the Environmental Monitoring Plan (whose implementation was established by an operating protocol between the ARPAB and the ENI company in 2011 in compliance with the DD.GG.RR. 313/2011 and 627/2011). This operating protocol defines an integrated environmental monitoring process implemented in the framework of the Project of modernization and improvement of production performance of the Val d'Agri Oil Centre of the Integrated Environmental Authorisation - IEA. It aims at characterizing the impacts caused by the oil extraction activities on air, soil and subsoil matrices in an area of $13 \mathrm{~km} \times 8 \mathrm{~km}$ surrounding COVA as well as to assess their temporal trends. Table 8 summarises the analysed parameters and the monitoring equipments with reference to the investigated matrices.

Some preliminary consideration concerning air quality and surface and wastewater reinjection quality can be made from the analysis of current available data.

In particular, in the framework of the activities of the Environmental Observatory (OAVDA, 2013), a preliminary analysis of air quality data referred to the period from 28 February to 13 June was performed. This analysis highlighted that high concentrations of all pollutants and in particular of volatile organic compounds $\left(\mathrm{C}_{6} \mathrm{H}_{6}, \mathrm{NO}_{x}\right.$, toluene, ethylbenzene) probably originated by the oil/gas treatment activities were recorded by the monitoring station close to COVA. Also $\mathrm{H}_{2} \mathrm{~S}$ concentrations were higher than the values reported by the World Health Organization (WHO) guidelines (WHO, 2000) and $\mathrm{O}_{3}$ threshold value was exceeded the allowed highest number of times.

Concerning the groundwater quality, the ARPAB data did not point out significant problems for the Montemurro municipality (ARPAB, 2013a). 
Table 8. Framework of synthesis parameters, and monitored environmental components. Source: OAVDA.

\begin{tabular}{|c|c|c|c|}
\hline Environmental & $\begin{array}{l}\text { Analyzed parameters (in situ and/or labo- } \\
\text { ratory measurements) }\end{array}$ & $\begin{array}{l}\text { Sampling } \\
\text { frequency }\end{array}$ & $\begin{array}{l}\text { Monitoring } \\
\text { equipments }\end{array}$ \\
\hline \multirow[t]{3}{*}{ Air } & $\begin{array}{l}\mathrm{SO}_{2}, \mathrm{O}_{3}, \mathrm{CO}, \mathrm{NO}, \mathrm{NO}_{2}, \mathrm{NO}_{x}, \mathrm{PM}_{2,5} \text {, } \\
\mathrm{H}_{2} \mathrm{~S}, \mathrm{CH}_{4}, \mathrm{NMHC}, \mathrm{THC}, \mathrm{VOCs}, \mathrm{C}_{6} \mathrm{H}_{6} \text {, } \\
\text { toluene, ethylbenzene and m, p, o-xylenes } \\
\text { (BTEX); odorous compounds-sulfur mer- } \\
\text { captans; measure the concentration of } \\
\text { radon gas }\end{array}$ & continuous & \multirow[t]{2}{*}{$\begin{array}{l}4 \text { fixed } \\
\text { monitoring } \\
\text { stations }\end{array}$} \\
\hline & $\begin{array}{l}\text { PAHs and } \mathrm{Al}, \mathrm{As}, \mathrm{Cd}, \mathrm{Cr}, \mathrm{Mn}, \mathrm{Ni}, \mathrm{Pb}, \mathrm{Fe} \text {, } \\
\mathrm{Cu}, \mathrm{Zn}, \mathrm{Tl}, \mathrm{Sb} \text { and } \mathrm{V}\end{array}$ & - & \\
\hline & $\begin{array}{l}\text { temperature, pressure, relative humidity, } \\
\text { precipitation, global radiation and net } \\
\text { speed and wind direction, UVW sonic ve- } \\
\text { locity components and sonic temperature }\end{array}$ & continuous & \\
\hline Groundwater & $\begin{array}{l}\text { - pH, temperature, turbidity, water ta- } \\
\text { ble depth, dissolved oxygen, conductivity, } \\
\text { salinity, redox potential } \\
\text { - IPA, sulfates, metals, hydrocarbons with } \\
\mathrm{C}<12 \text { hydrocarbons with } \mathrm{C}<12 \text {, aro- } \\
\text { matic organic compounds }\end{array}$ & monthly & 4 piezometers \\
\hline Surface water and sediment & $\begin{array}{l}\text { physico-chemical parameters } \\
\text { processing of indexes: I.B.E, Trophic and } \\
\text { functional indices, indices of diversity, } \\
\text { LIM, SECA, S.A.C.A. }\end{array}$ & monthly & $\begin{array}{l}7 \text { sampling } \\
\text { stations }\end{array}$ \\
\hline Noise & Sound levels for day and night & continuous & 4 stations \\
\hline Odor emissions & $\begin{array}{l}\text { "The monitoring of odor emissions will } \\
\text { be made on the basis of an adequate scien- } \\
\text { tific study with direct applications in the } \\
\text { surrounding territory on the Val d'Agri } \\
\text { Oil Centre in collaboration with scien- } \\
\text { tific institutions and research organiza- } \\
\text { tions" (protocol implementation in devel- } \\
\text { opment) }\end{array}$ & & \\
\hline
\end{tabular}

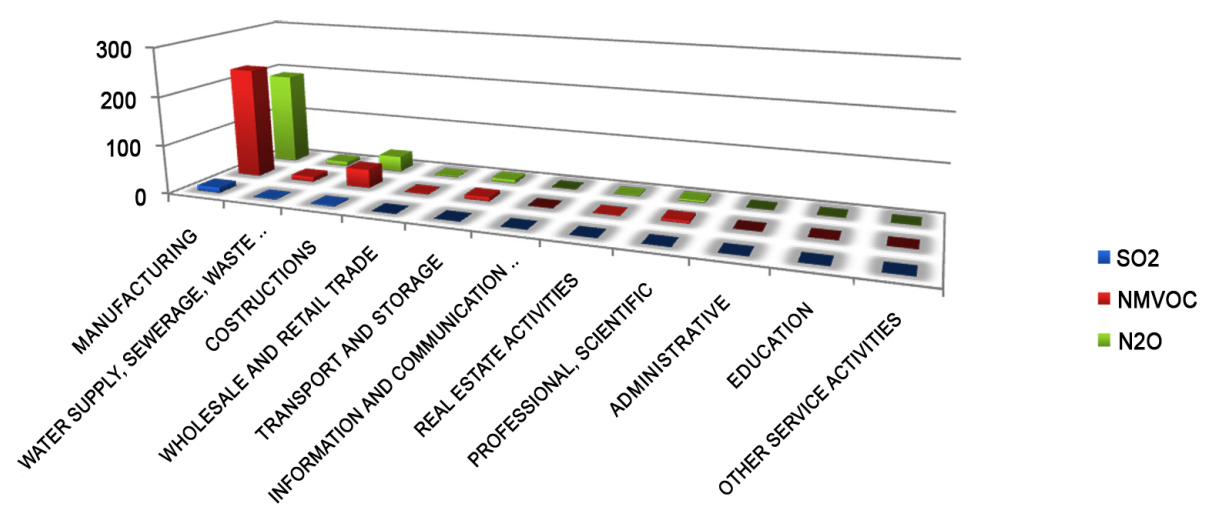

Figure 8. Local air pollutant emissions from energy processes by sector $\left(\mathrm{kg} \mathrm{yr}^{-1}\right)$.

A monitoring project to assess the quality of wastewater reinjection of Costa Molina 2 was carried out in 2010, 2011,
2012 and the first 6 months of 2013. The results of these monitoring campaigns, partly reported in (ARPAB, 2013b) 
Table 9. Main response indicators selected for the case study.

\begin{tabular}{lll}
\hline Strategic/political instrument & Measure & Objective/scope \\
\hline $\begin{array}{l}\text { Basilicata region environmental } \\
\text { observatory Val d'Agri }\end{array}$ & $\begin{array}{l}\text { (1) Monitoring project; } \\
\text { (2) Implementation of dynamic databases; } \\
\text { (3) Development of training projects, }\end{array}$ & $\begin{array}{l}\text { (1) Environmental monitoring } \\
\text { (2) Archiving and managing of } \\
\text { environmental data; }\end{array}$ \\
& $\begin{array}{l}\text { (4) Environmental Assessment } \\
\text { (5) Implementation of several research projects } \\
\text { on the environmental and health issues }\end{array}$ & $\begin{array}{l}\text { aimed at ensuring to the citizenship a correct } \\
\text { and well-documented information on envi- } \\
\text { ronmental issues; }\end{array}$ \\
& & $\begin{array}{l}\text { (4) Study and verification of compatibility } \\
\text { among existing activities and the principles } \\
\text { of biodiversity conservation; }\end{array}$ \\
& (5) Population and health assessment and \\
& surveillance
\end{tabular}

Action plan for the protection of air quality in the municipalities of Viggiano and Grumento Nova

ERDF operational programme of Basilicata region

Regional Environmental Plan
$20 \%$ reduction of $\mathrm{SO}_{2}$ and $\mathrm{H}_{2} \mathrm{~S}$ emissions and definition of four attention levels

(1) Supporting the entrepreneurship

(2) Improving the sustainable use of environmental resources, the efficiency and the management of decision-making process;

(1) Reduction of energy consumption and energy bills;

(2) Increase of the production of electric and thermic energy from RES;

(3) Creation of a district energy

in the Val d'Agri
Improvement of air quality

Territorial development, environmental certification to facilitate the settlement of the productive and tourist activities

(1) Energy savings and improved energy efficiency of public and private buildings;

(2) Larger energy distributed generation from RES

(3) To support research and technological innovation,

(4) Sustainable mobility

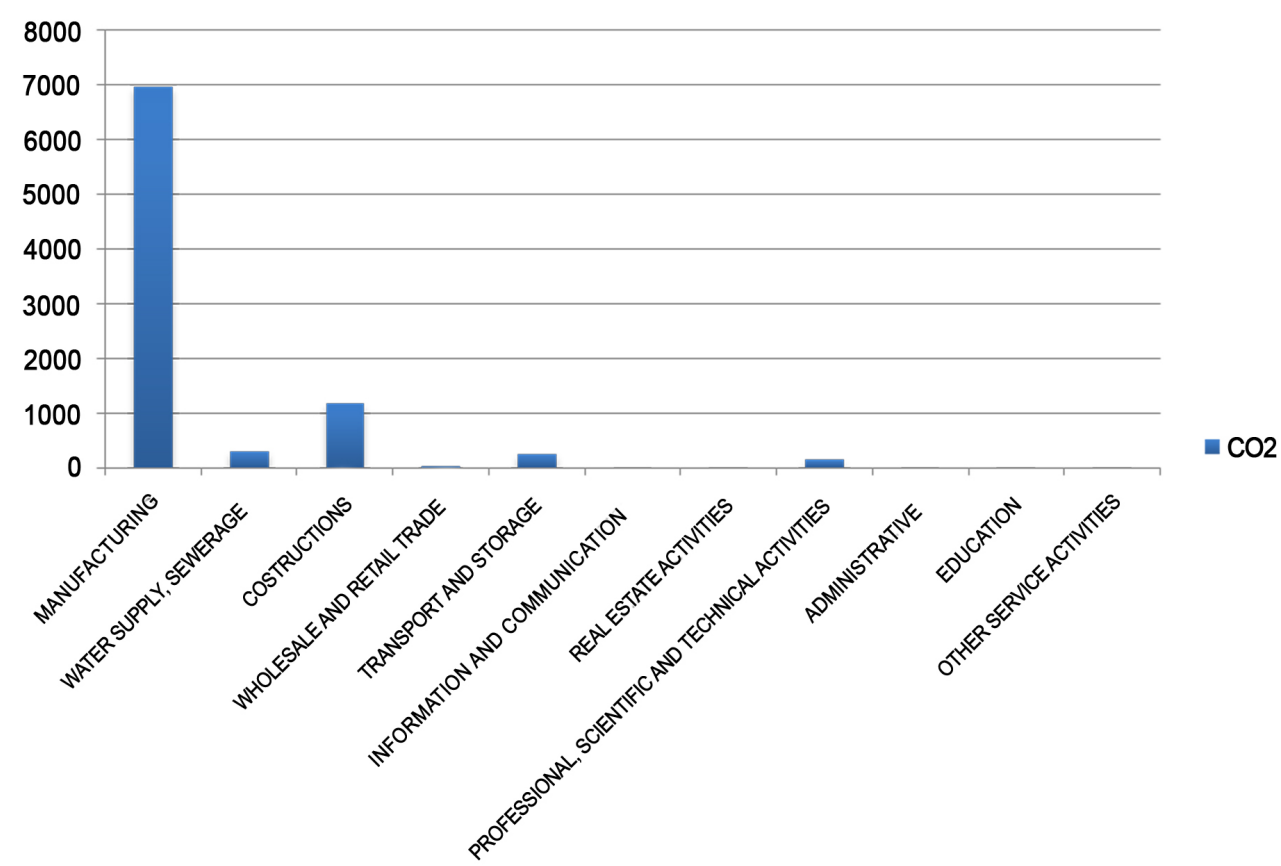

Figure 9. $\mathrm{CO}_{2}$ emissions from energy processes by sector (tons). 
Table 10. Type and capacity of RES systems installed in the Alta Val d'Agri industrial area (data from direct survey).

\begin{tabular}{lll}
\hline RES & Installed capacity $[\mathrm{kWp}]$ & Type of system \\
\hline PV & 200 & Totally integrated on roof \\
PV & 20 & Partially integrated on roof \\
PV & 200 & Not integrated \\
PV & 4500 & On land \\
\hline
\end{tabular}

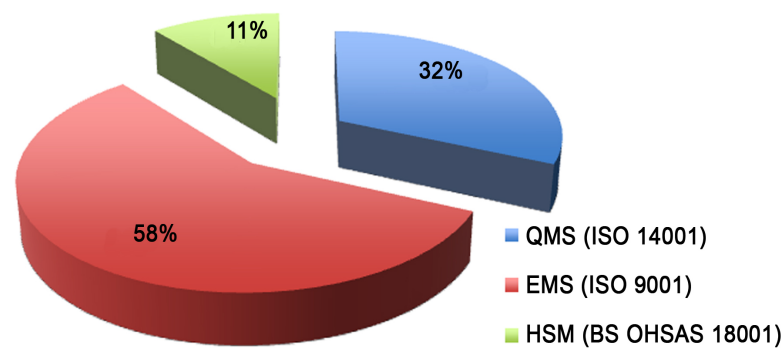

Figure 10. Percentage distribution of the different accreditation schemes of industrial processes (Source: CNR-IMAA elaboration on ACCREDIA data).

pointed out that some analytes, like iron and total hydrocarbons exceeded the regulatory limits.

Other interesting results can be inferred from a census of the companies that adopted quality certifications of their performances as:

- ISO 9001 Quality Management Systems (QMS)

- ISO 14001 Environmental Management Systems (EMS)

- BS OHSAS 18001 Health and Safety Management Systems (HSM).

Based on the ACCREDIA official data (ACCREDIA, 2013), only 14 companies have adopted quality management systems to improve their performances (Fig. 10).

In addition to that, no company has adopted till now the more restrictive European Eco-Management and Audit Scheme regulation (EMAS, 2013) that requires as compulsory steps the definition of the company environmental policy, the adoption of an environmental management system, an environmental audit for the periodic evaluation of environmental performances of the company and an environmental statement.

The analysis of the currently available data points out the lack of validated data time series for all the considered environmental matrices to perform a thorough assessment of the state of environment in the case study area, as well as to monitor the evolution of the most important pollutant phenomena. In particular, there is a lack of knowledge about the period before the start of mining activities and this hampers a full evaluation of the changes occurred in the time and the cause-effects relationships.

\subsubsection{Responses}

To compensate the environmental impact of the mining activities as well as to guarantee adequate life conditions and information to the population, a set of measures have been implemented. The main considered strategies with a synthesis of the pursued aim and the planned measures are reported in Table 9. These include policy strategies aimed to control/improve the environmental conditions, policy and incentives to foster technological innovation, business creation and development and to improve information to the community. Concerning the impact of mining activities and oil treatment processes, several measures were undertaken by the companies to limit the damage and to verify their environmental performances, extensively reported in the previous paragraphs. Among the policy strategies, it is worth noting the institution of the Environmental Observatory of Val d'Agri that participated in several research projects on environmental and health issues, organised monitoring campaigns, managed and analysed environmental data ensuring a proper and well-documented information to population, promoted scientific conferences and dissemination events.

Among the response measures a noticeable interest arouses also the Action plan for air protection of quality in the town of Viggiano and Grumento Nova, established with the Regional Decree (DGR 1640/2012, 2013). This plan is aimed to improve air quality, providing for a $20 \%$ reduction of the threshold values of $\mathrm{SO}_{2}$ and $\mathrm{H}_{2} \mathrm{~S}$ and the definition of four attention reference levels for exceeding the threshold values. According to this action plan, specific measures should be implemented in order to prevent and limit the causes of environmental/air quality degradation.

Specific measures to promote the development and competitiveness of the regional production system were also provided by the European Regional Development Fund (ERDF) Operational Programme of Basilicata Region, in particular by the ERDF Innovative Actions 2000-2006 (Regional Programme of Innovative Actions in Basilicata - Italy; ERDF, 2007), the Regional Law no. 1/2009, 2009 (Basilicata law no. $1 / 2009$ ) and the 2007/2013 ERDF Programme (Operative Programme Val d'Agri-Melandro-Sauro-Camastra; ERDF, 2013), that provides for specific actions to promote the territorial development, the environmental certification and to facilitate the settlement of the productive and tourist activities in the case study.

With regard to energy issues, financial incentives were granted to boost energy production from Renewable Energy Sources (RES) (large energy distributed generation) in order to valorise endogenous resources and to limit the use of fossil fuels. These incentives fostered a noticeable diffusion of PV systems as reported in Table 10. 
The Regional Environmental Energy Plan (PIEAR, 2010) foresees a reduction of energy consumption and bills, by increasing energy savings and energy efficiency in public and private buildings, the production of electric and thermal energy from RES and by creating an energy district in the Val d'Agri with the aim of supporting research and innovation and to promote sustainable mobility.

Despite the existence of several planning strategies, further measures would be necessary to improve the management and the environmental performances of this area. A main need is the improvement of infrastructure and common facilities (i.e. the completion of natural gas distribution network). In addition a wide application of audit scheme (EMAS) certification to the Alta Val d'Agri industries should be supported to foster a sustainable development of the area. A territorial approach based on EMAS scheme diffusion can be considered a great opportunity to pursue synergically public, private, social and industrial targets as well as to reconcile different interests emerging in the local context, resulting in an approach of increasing importance for the sustainable development of industrial districts (Daddi et al., 2012).

\section{Conclusions}

Mining activities are at the same time a resource for the territory and an important source of impacts causing severe damages to the environment as soil erosion, loss of biodiversity, air, soil and groundwater pollution phenomena that may significantly affect local population.

The DPSIR methodology describes comprehensively the cause-effect relationships among the different components including the recovery plans and strategies. In particular, the DPSIR framework highlights weak and strength points facilitating the monitoring of the state of environment, managing the critical phenomena and valorising the endogenous resources to improve environmental quality and standard of living.

This paper presents a preliminary environmental impact study and assessment of the Alta Val d'Agri industrial district. The investigation was mainly aimed at identifying the critical factors for the sustainable development of business activities, currently hindered by insufficient infrastructures.

The work performed so far provides a basic reference framework for further investigations and to evaluate the potential risks caused by the mining activities in a vulnerable area with peculiar environmental and geographical features.

Additional data (not currently available) are necessary to perform an in-depth characterization of the study area and of the impacts of industrial activities in order to characterize the different environmental matrices and to carry out a complete environmental balance. Further studies will be therefore performed in the future also integrating different methodologies to improve the description of the study area and to define tailored guidelines for its sustainable development.
Acknowledgements. This work was carried out in the framework of the research agreement between the Basilicata Region Environmental Observatory Val d'Agri and the National Research Council of Italy - Institute of Methodologies for Environmental Analysis CNR-IMAA.

Edited by: V. Lapenna

\section{References}

Agenzia Nazionale per la Protezione dell'Ambiente (ANPA), Centro Tematico Nazionale (CTN) Atmosfera, Clima, Emissioni (ACE): Manuale dei fattori di emissione nazionali, 2002.

Agenzia Nazionale per le nuove Tecnologie, l'Energia e lo Sviluppo Economico Sostenibile (ENEA): Statistiche Energetiche Regionali 1988-2008, available at: http://www.efficienzaenergetica. enea.it/doc/2011/sier/17_Basilicata.pdf (last access: 20 Febraury 2014), 2012.

Agenzia Regionale per la Protezione dell'Ambiente Basilicata (ARPAB), internal communication, 2012.

Agenzia Regionale per la Protezione dell'Ambiente Basilicata (ARPAB): Report Campionamento acque superficiali del 19/09/2013 Comune di Montemurro - C/da La Rossa, Fonte dati: Ufficio Risorse Idriche Dipartimento di Potenza, 2013a.

Agenzia Regionale per la Protezione dell'Ambiente Basilicata (ARPAB): Risultati dell'attività di controllo delle acque sotterranee relativa a 8 piezometri e 2 sorgenti nel territorio interessato dal passaggio della condotta di reiniezione delle acque derivanti dall'estrazione e separazione degli idrocarburi del Centro Olio Val d'Agri, Fonte dati: Ufficio Suolo e Rifiuti Dipartimento di Potenza, 2013b.

Aziende Riunite Gestione Aree Industriali Potentine (ARGAIP), internal communication, 2012.

Basilicata Region Law no. 1/2009: Legge regionale per lo Sviluppo e la Competitività del Sistema Produttivo Lucano, B.U.R. Basilicata 9, available at: http://www.consiglio.basilicata.it/consiglionew/site/Consiglio/ detail.jsp?sec $=107173 \&$ otype $=1150 \&$ id $=100261 \&$ anno $=2009$ (last access: 28 October 2014), 2009.

Basilicata Region Law no. 9/2011: Disposizioni urgenti in materia di microzonazione sismica - BUR 17, 2011.

Basilicata Region and European Union: (ERDF) Innovative Actions 2000-06, Regional Final Report, Regional Programme of Innovative Actions in Basilicata - Italy, available at: http://www.pofesr. basilicata.it/eng/ (last access: 28 October 2014), 2007.

Basilicata Region (DGR 1640/2012): Piano di Azione per la protezione della qualità dell'aria nei comuni di Viggiano e Grumento Nova, available at: http://www.regioni.it/download.php? $\mathrm{id}=280553 \&$ field $=$ allegato $\&$ module=news (last access: 28 October 2014), 2013.

Basilicata Region and European Union (ERDF): Operative Programme Val d'Agri-Melandro-Sauro-Camastra, available at: http://www.povaldagri.basilicata.it/povaldagri/Webby.do? service=reload (last access: 28 October 2014), 2013.

Chamber of Commerce and Industry of Potenza, internal communication, January 2013.

Consiglio Regionale di Basilicata: Piano di Indirizzo Energetico Ambientale Regionale (PIEAR), Regional Official Bulletin (BUR) 2, 2010. 
Consorzio per lo sviluppo industriale della provincia di Potenza (ASI): direct survey, 2012.

Cosmi C., Loperte S., Macchiato M., Marmo G., Pietrapertosa F., Proto M., Salvia M., The environmental balance: an application to an industrial district of Southern Italy for supporting strategic sustainable planning, Fresenius Environmental Bulletin, ISSN 1018-4619, Volume 15-No.8a, 2006.

Council of the European Union, Review of the EU Sustainable Development Strategy (EU SDS) - Renewed Strategy, 10117/06 Brussels, 9 June, 2006.

Daddi T., De Giacomo M.R., Testa F. and Tessitore S., Cluster approach and innovation in four industrial clusters of Tuscany region (Italy) - Environmental Economics Vol 3, Issue 2, 2012 Directive 2008/1/EC of the European Parliament and of the Council of 15 January 2008 concerning integrated pollution prevention and control, available at: http://eur-lex.europa.eu/legal-content/ EN/TXT/?uri=CELEX:32008L0001 (last access: 2 April 2014), 2008.

Eco-Management and Audit Scheme (EMAS), available at: http: //www.isprambiente.gov.it/it/certificazioni/emas (last access: 3 April 2014), 2013.

Ente Italiano di Accreditamento (ACCREDIA), available at: http: //www.accredia.it/ (last access: 28 October 2014), 2013.

EMEP/EEA air pollutant emission inventory guidebook, available at: http://www.eea.europa.eu/publications/ emep-eea-emission-inventory-guidebook (last access: 28 October 2014), 2009

ENI (Ente Nazionale Idrocarburi) ENI in Basilicata, Local Report, available at: http://www.eni.com/files/documenti/ eni-in-basilicata.pdf (last access: 28 October 2014), 2013.

European Environment Agency (EEA): Europe's Environment: the Dobris Assessment, edited by: Stanners, D. and Bourdeau, P., Copenhagen, available at: http://www.eea.europa.eu/ publications/92-826-5409-5 (last access: 28 February 2014), 1995.

European Environment Agency (EEA): Technical report No 1/2005 EEA core set of indicators Guide, ISSN 1725-2237, 2005.

European Environment Agency (EEA) website, available at: http://www.eea.europa.eu/data-and-maps/indicators\#c7= all\&c5=\&c0=10\&b_start=0 (last access: 23 November 2013), 2012.

Eurostat Methodologies and Working papers: NACE Rev.2 - Statistical classification of economic activities in the European Community, ISSN 1977-0375, 2008.

Eurostat Statistical Books, Sustainable development in the European Union, 2011 monitoring report of the EU sustainable development strategy, Luxembourg 2011 Istituto Superiore per la Protezione e la Ambientale (ISPRA): Annuario dei dati ambientali (Environmental Data Yearbook), available at: http://annuario. isprambiente.it/content/indice/ (last access: 23 November 2013), 2012.

Karageorgis, A. P., Kapsimalis, V., Kontogianni, A., Skourtos, M., Turner, R. K., and Salomons, W.: Impact of 100-year human interventetions on the deltaic coastal zone of the Inner Thermaikos Gulf (Greece): A DPSIR framework analysis, Environ. Manage., 38, 304-315, 2006.

Legislative Decree no. 152/1999: Disposizioni sulla tutela delle acque dall'inquinamento e recepimento della direttiva 91/271/CEE concernente il trattamento delle acque reflue ur- bane e della direttiva 91/676/CEE relativa alla protezione delle acque dall'inquinamento provocato dai nitrati provenienti da fonti agricole, available at: http://www.camera.it/parlam/leggi/ deleghe/testi/99152dl.htm (last access: 20 January 2014), 1999.

Legislative Decree no. 152/2006: Norme in materia ambientale, available at http://www.camera.it/parlam/leggi/deleghe/06152dl. htm (last access: 20 January 2014), 2006.

Ministerial Decree no. 52/2011: Regolamento recante istituzione del sistema di controllo della tracciabilità dei rifiuti, ai sensi dell'articolo 189 del decreto legislativo 3 aprile 2006, no. 152 e dell'articolo 14-bis del decreto-legge $1^{\circ}$ luglio 2009, no. 78, convertito, con modificazioni, dalla legge 3 agosto 2009, no. 102, 2011.

Naviglio, L., Castorina, M., Barbato, F., Paci, S., Sbrana, M., and Signorini, A.: DPSIR: An Environmental Analysis Tool Useful for management Purposes, ENERGIA, AMBIENTE E INNOVAZIONE, ENEA 5/2009, 2009.

Niemeijer, D. and De Groot, R. S.: A conceptual framework for selecting environmental indicator sets, available at: www.elsevier. com/locate/ecolind (last access: 23 November 2013), 2012.

Nilsson, M., Wiklund, H., Finnveden, G., Jonsson, DK., Lundberg, K., Tyskeng, S., and Wallgren, O.: Analytical framework and tool kit for SEA follow-up, Environ. Impact Assess. Rev., 29, 186199, doi:10.1016/j.eiar.2008.09.002, 2009.

Osservatorio Ambientale della Val d'Agri (OAVDA), available at: http://www.osservatoriovaldagri.it/getpage.aspx?id=1 (last access: 28 October 2014), 2013.

OECD: Environmental indicators, OECD OECD Core Set, Paris, 1-157, 1994.

Piemonte Region and Regional Agency for the Protection of the Environment of Piemonte: Pressioni Ambientali Rischio Industriale in Lo Stato dell' Ambiente in Piemonte, ISBN 978-8874791-255, 2013.

Resolution of the Regional Council of Region of Basilicata no. 313 11/03/2011 - quarter par. 29 of Legislative Decree 152/2006 and subsequent amendments - Integrated Environmental Authorization (IEA), 2011.

SINA Net Rete del Sistema Informativo Nazionale Ambientale: Fattori di emissione per le sorgenti di combustione stazionarie in Italia, available at: http://www.sinanet.isprambiente.it/it/siaispra/serie-storiche-emissioni/fattori-di-emissione-per-lesorgenti-di-combustione-stazionarie-in-italia/view, (last access: 28 April 2014), 2012.

Sviluppo Basilicata: SEPA Project: Viggiano industrial area as a sustainable and equipped productive area, feasibility study, p. 72, available at: http://webcache.googleusercontent.com/search?q= cache:KOXYhdwZbBcJ:www.southeast-europe.net/document. cmtFidD154+\&cd=3\&hl=it\&ct=clnk\&gl=it, last access: 26 August 2015, 2011.

The Seveso 3 - EU Directive of July 4, 2012 (EU/2012/18), available at: http://eur-lex.europa.eu/legal-content/EN/TXT/ ?uri=CELEX:32012L0018 (last access: 10 April 2014), 2012.

World Health Organisation (WHO): Regional Publications: Air quality guidelines for Europe - Second Edition, European Series, No. 91, available at: http://www.euro.who.int/en/ health-topics/environment-and-health/air-quality/publications/ pre2009/who-air-quality-guidelines-for-europe,-2nd-edition, -2000-cd-rom-version (last access: 28 October 2014), 2000. 